\title{
Editorial - Property investment - What is it worth?
}

\section{Introduction}

It is funny how the COVID pandemic has changed our perception of life. It has changed the way in which we behave and that, quite naturally, has changed how we use and view property, which, in turn, using basic Ricardian economics, impacts upon its value. Let me explain.

In lockdown, some of us started to feel that the enforced break from the rat race was an opportunity to move away from the consumer economy of wanting everything now. Instead, we started enjoying the free things in life: an appreciation of the countryside (for those lucky enough to be locations where our daily exercise allowed such excursions), the mellowness of rest and the quietness of just being. But, sadly for everyone so blessed, there were others who found the whole experience stressful and distressing. Different people in different circumstances experience different things. That will always be the case.

But, there were some tangible observations about how people started to recognise the worth of the things that they bought and "needed" in this the new normal. And again, I must preface this observation by noting that this definitely did not apply to everyone, but there were many households in the UK that had stable incomes but with less expenditure on travel or going out or other recreational pursuits. In other words, they had an increase in their disposable income and a limited array of possibilities for expenditure. Of course, due to the uncertainty of the pandemic, people in such circumstances have increased their savings or cleared their debts, but there has been enough people who have simply transferred their expenditure to other avenues that were both available to them and to other pursuits.

And in the world of supply and demand, that changed everything. For example, as soon as garden centres became "essential retail" in the UK, they, if you will pardon the pun, bloomed. People trapped at home either through deliveries or social-distanced shopping quite naturally decided to spend time and energy on improving their gardens and open spaces. And the price of plants and ornaments and pots and soil and everything horticultural went up. Then the supply of the same failed to keep up with demand and prices increased again. It was the same with DIY, decorating, woodwork and home improvements; all of them boomed and prices increased. It is simple economics in a microcosm.

So what does that have to do with property and value? It is really simple; people will pay more for the things that they think are "worth it". Now this can be explained in economics by supply and demand curves, but let us talk about it in terms of price, value and worth. These three little words are often mistakenly thought to be synonyms of each other, but the three words that actually explain how all markets, and specifically property markets, work.

\section{Price, value and worth}

Worth is the driver of price. A successful bidder, at auction or tender, will be the one who thinks that the item is worth the most and will outbid other bidders. This will determine the price - the observable exchange point. And value is just a professional estimate of price when there is no actual sale.

Markets are driven by changes in perceived worth. Prices rise when more people increase their worth assessment of a particular item. Hence, people witnessed the rise in the price of horticultural items during lockdown. But the same is true of rents and capital value of

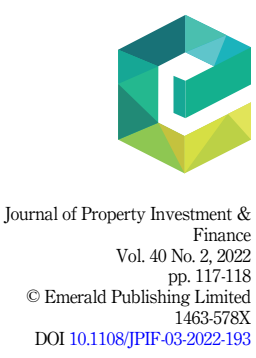


JPIF

40,2

118

properties. Everything is linked in an economic eco-system. The value of garden centres increased last year as the demand for their products increased. The rent on logistic units increased last year as the demand for e-warehousing increased exponentially with the rise in online shopping. Conversely, high street retail suffered not just because of the lockdown but because the pandemic accelerated the existing trend away from physical shopping such that turnovers of many shops fell significantly and the already tenuous relationship between the tenant's affordability and the rent demanded (and agreed and fixed in better times) by the landlord died.

Indeed, when talking to corporate occupiers, be it of retail or office space, it is clear that many will not be able to afford the rents previously agreed and that survival will only be secured if rents are re-based significantly. Indicative figures of $40-50 \%$ falls in retail, and office rents are not unusual. And this then brings into play another calculation of worth; this time, the worth of the property to the owner. They may decide that it is no longer worth keeping the property as, say, a retail unit and decide that the potential returns are better if the property is converted to, say, residential. So as the consumer worth of the space declines, the retailer's worth of the space declines and the worth of the space to the owner also declines. Everything flows and that, in turn, can either change the owner attitude to an acceptable return for the asset if left as a shop or trigger a repurposing, refurbishment or redevelopment as another use.

This relationship between the end user and the owner of the asset has always been so, but the abrupt readjustment of markets during COVID has highlighted and reminded us of how linear the connection can be.

As I have said many times, to understand property investment, you need to understand people and consumer behaviour. If you solely look at property assets as financial cash flows, you will be exposed every time market sentiment shifts. I am not saying that being a disciple of behaviourism will give you a crystal ball or indeed the tools to manage change better, but it will help you understand property and be proactive with your portfolio. Look at the fundamentals, understand how markets work, understand how people think and try to recognise what people want and the worth of achieving that desire. If you do that, you will understand property markets and that will help you maximise the worth of your assets.

As Benjamin Franklin once said, "An investment in knowledge pays the best interest."

(Editorial based on a paper published in the Property Chronicle, Autumn 2021)

Nick French

Real Estate Valuation Theurgy, Frilsham, UK 